\title{
東京タワーの周辺街路における可視域・認知域・不認知域に関する考察 A STUDY ON VISIBLE, RECOGNIZABLE AND NON-RECOGNIZABLE AREAS AT THE SURROUNDING STREETS OF THE TOKYO TOWER
}

\author{
大竹由夏*，花里 俊廣** \\ Yuka OTAKE and Toshihiro HANAZATO
}

\begin{abstract}
The purpose of this study is to clarify the factor of "the visible area", "the recognizable area" and "the non-recognizable area" of the Tokyo Tower from its surrounding streets.

The study investigates the Tokyo Tower figure's recognition through pictures and interviews taken from different streets locations. The Tokyo Tower street visibility and its relationship between the visible areas and the viewing distance inside a 1000 meter radio were also examined. The study has identified that the visible areas decrease proportionally according to the viewing distance. By contrast, the recognizable areas present an inverse proportional relation to the viewing distance and these areas were found in streets located in the west, north-west and south areas of the Tokyo Tower. The recognizable areas are presented only in particular streets inside 200 meter radio where the recognition of the Tokyo Tower is hardly because is hidden by trees or buildings, but possible due to the top part visibility. Additionally, the recognizable areas were increasable identified in areas above 200 meter radio.
\end{abstract}

Keywords : the Tokyo Tower, Streets, Visibile Areas, Recognizable Areas, Non-Recognizable Areas 東京タワー, 街路, 可視域, 認知域, 不認知域

\section{1 はじめに}

\section{1 研究の背景と目的}

一般的に、ランドマークは都市のしかるべきところから視覚的に 確認できるべきだと考えられている。そのような都市のランドマー クの眺望を確保する方策として、例えば英国・ロンドンにおける「戦 略的眺望」やフランス・パリにおける「フュゾー」が知られている。 前者はロンドン市内の 10 カ所の眺望地点（視点場）から眺望を保護 しようとするものであり、後者はパリ市内 45 地点からの景観を保全 するものである ${ }^{1)}$ 。東京都では「東京都景観計画 ${ }^{2}$ 」を策定し 2007 年から施行しており、その中で、国会議事堂や東京駅丸の内駅舎な どの眺望を保全するために景観誘導がなされている。これらの方策 は、建物の正面に視点場注 1) を置き該当する建物の全貌が見えるよう に眺望を保全するものであり、視線の通った街路や広場に建物があ る都市の構造において成り立つものである。

戦後、経済発展に伴い、日本の都市中心部の建築物は高層化して いる。そのため、都市中心部にあるランドマークの見える場所は減 少している ${ }^{3)}$ 。その典型的な例として東京タワーが挙げられる ${ }^{4)}$ 。

日本には、江戸見や富士見のようなランドマークが見える場所を 示す言葉があり、古くからランドマークの見える場所は親しまれ、
重要視されてきた。東京のランドマークである東京タワー注2)もその 見える場所は人々に親しまれ、重要であると考えられる。

東京タワーの周辺を実際に訪福、東京タワーの見える場所を探し てみると、東京タワーの下部がビルや木々に隠されその上部しか見 えないためそれが東京タワーであると認知できない場所が多いこと がわかる。たとえ、東京タワーが見えても、それと認知できなければ、 見えていない状況と同様であろう。

そこで本稿の目的は、東京タワーの見える場所と認知できる場所 を実証的かつ定量的に明らかにすることにある（表 1)。そのために、 東京タワーが見えるか見えないかという可視・不可視という側面と、 東京タワーがあると認知できるかできないかという認知・不認知と いう側面に着目し、東京タワーを見ることができる領域である「可 視域」を、東京タワーを認知できる領域である「認知域」と認知で きない領域である「不認知域」に区別した。

具体的には、第一にインタビュー調査により東京タワーをそれと 認知できる見え方を把握する。第二に東京タワーの可視域である街 路を地図上に表記し、視距離と可視割合との関係を定量化する。第 三に東京タワーの認知域である街路を地図上に表記し、視距離と認 知割合との関係を定量化する。第四に可視域と認知域との差である 不認知域と設定し、不認知域である街路を地図上に表記し、視距離
* 筑波大学人間総合科学研究科 博士後期課程・修士 (デザイン学)

** 筑波大学人間総合科学研究科 教授 · 博士 (工学)
Ph. D. Program, Graduate School of Comprehensive Human Sciences, Univ. of Tsukuba, M. Des.

Prof., Graduate School of Comprehensive Human Sciences, Univ. of Tsukuba, Dr. Eng. 
表 1 東京タワーの可視域 · 不可視域 - 認知域 · 不認知域について

\begin{tabular}{|c|c|c|c|}
\hline & \multicolumn{2}{|c|}{$\begin{array}{c}\text { 東京タワーが } \\
\text { 見えるか見えないか }\end{array}$} \\
\hline & & 見える & 見えない \\
\hline \multirow{2}{*}{$\begin{array}{c}\text { 東京夕ワーが } \\
\text { 認知できるか } \\
\text { できないか }\end{array}$} & $\begin{array}{l}\text { 認知 } \\
\text { できる }\end{array}$ & & \\
\hline & $\begin{array}{c}\text { 認知 } \\
\text { できない }\end{array}$ & & \\
\hline
\end{tabular}

と不認知割合との関係を定量化する。

これまでにも、ランドマークの可視域は検証されてきた ${ }^{3(5) 6) 778) 。 ~}$ 本稿では、東京タワーを対象に、東京タワーの可視域を認知域と不 認知域に区別し、視距離との関係を定量的に考察する。ランドマー クの物理的な認知性 ${ }^{\text {注 } 31}$ は、その建造物や周辺街路によって異なると 考えられ、認知できる見え方や認知できる場所を考慮して計画する ことで、そのランドマークの認知域を広めることができよう。

東京タワーの視点場として、東京タワーの周辺街路のほかにも、 東京タワーの領域の外、例えば臨海地区などが挙げられる。本稿では、 周辺街路に着目して検証する。

\section{2 既往研究}

近年、都市景観への関心が高まり、2004 年には景観法が制定され た。それ以前から、都市景観に関する研究は様々になされてきた。 芦原 ${ }^{9)}$ は、世界各地の都市の構造や建築・空間について理論的に考 察し、人間のための美しい街並みをつくる手法を具体的に提案して いる。西村 ${ }^{10)}$ は、景観法制定前後の日本の様々な地域における景観 施策について実体的な方法を論じている。桐敷 ${ }^{11)}$ は、東京の街路構 造の基礎となる江戸時代の街路計画について、山获や丘陵を目標と する基準線を配置した既存の地形条件を活かした計画であると述へ、 芝丘陵地も目標とされた地形条件のひとつであるとの指摘をしてい る。本稿で対象とする東京タワーの敷地は芝丘陵地に位置する。さ らに、横ら ${ }^{12)}$ は、低密度な時代や場所では「すき間」や「奥」とい う日本独特の空間概念が日本的意味を保持してきたと言及し、密度 が超えたところでは新しい原則を発見しなければならないと述べて いる。松本ら ${ }^{13) 14)}$ は、街路空間の魅力を考えるときには十分な視覚 的配虑が必要であるとし、その乱雑・整然性を引き起こす物的要因 を明確化しており、さらに瀬田ら ${ }^{15)}$ は、ゆらぎ理論を適用して街路 景観に形態変化を与えることで街路空間全体に適度な乱雑性と整然 性のある魅力ある空間が作り出せる可能性を得ている。これらの研 究から、都市景観を理解する上で、その街路構造を把握することが 重要であるとわかる。

ここで、近代の都市計画におけるランドマークの位置づけを明ら かにしたい。ランドマークは都市の景観を特徴づける要素であり、 リンチの研究 ${ }^{16)}$ を基礎に様々な観点から研究されてきた。津川 ${ }^{17)}$ は、 ランドマークに関する研究動向をまとめ検討することで、ランドマー クは景観・風景の要素の一つであり、象徴性、記号性、場所性、認 知性を発揮することを明らかにした。実際の都市におけるランドマー クの街路からの見え方を具体的に検証研究したものとしては、小林 $ら^{3)} 、$ 中井ら ${ }^{5)}$ 、伊庭野ら ${ }^{6)}$ の研究、また筆者らの研究 ${ }^{778)}$ が挙げら れる。これらの研究では、ランドマークが見えるか否かに着目し街 路からのランドマークの見える範囲を検証しているが、それそのも
のが認知できるかまでは検証されていない。

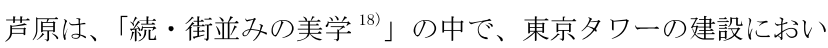
て都市計画的配慮や景観的配慮がなされていなかったことを述べて いる注4)。こういった指摘もあってか、東京タワーは東京を代表する ランドマークでありながら、都市計画の分野においてあまり研究対 象となってこなかったものと考えられる。

岡田 ${ }^{4)}$ は、東京タワーのイメージについて、新聞記事、歌謡曲の 歌詞、雑誌、観光ガイドブックを用い論じている。また、鮫島は「東 京タワー 50 年 ${ }^{19)} 」$ ので、東京タワーを題材としたナラティブ作品 について触れ、昨今では外から眺める東京タワーの存在感が語られ るようになったと述べている。また、筆者ら ${ }^{20)}$ は、メディアに表現 される東京タワーに着目し、視線・視点が自由に描ける漫画を事例 にそれらを通して東京タワーを含む都市景観を類似的に眺望してい るという立場から、仮想現実的な情景に基づいたランドマークであ ることを明らかにしている。

本稿は東京タワーの街路上の見える領域に関する実証的研究であ るが、視認性として可視性だけではなく認知性をとりあつかう点で 既往の研究とは異なる。

\section{2 東京タワーと認知できる見え方}

東京タワーは見えたとしても、タワー下部が建物等によって隠さ れ頂部のアンテナしか見えないような場合も多く、東京タワーとは 認知されにくい。このように東京タワーはそれが一定程度の分量見 えることによって、東京タワーとしての認知されるものと考えられ る。そこで、本章では、インタビューI I III の調査を行い、タワー のどの部分が見えると東京タワーと認知できるのかを検証した。

\section{1 インタビューI の調査方法}

東京タワーがどのくらい見えると東京タワーであると認知できる かをインタビューにより調查した。調査は、2014年8月に、東京タワー から 900mほど離れた場所に位置する大門交差点にて成人計 28 人に 対し、個別面接方式で行った。質問項目は表 2 に示す。表 3 に示し た調查結果は、面接者である筆者が回答を記入し、インタビュー終 了後各内容を整理分類し集計したものである。

調查方法は、（1）図 1 で示す東京タワーのみの画像を見せ、さら に（2）表 2 の質問をするという手順で行った。

（1）また、予備調査から現実の都市では東京タワーは建物等によっ て下部が隠されることが多いことがわかっていたので、図 1 に示す 東京タワーのみが写っていて、さらにタワーの下部が異なった分量 で隠された画像 9 枚を作成した。これらの画像は、東京タワーの公 式ホームページ上に揭載されている画像を筆者が加工したものであ る。1 は先端のアンテナまで (以下、先端から省略)、2 はデジタル アンテナまで、3 3 は特別展望台下の白色部分まで、4は特別展望台下 の赤色（正式にはインターナショナルオレンジ）部分まで、 5 は大 展望台上の白色部分まで、6 は大展望台上の赤色部分まで、7 は大展 望台まで、8 は大展望台下の中腹まで、9はタワー全体を表した画像

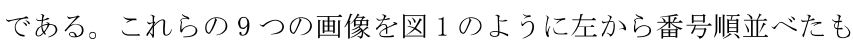
のを A4 サイズの紙に印刷し被験者に見てもらった。

（2）そして、図1を見てもらいながら、表 2 で示すように質問 1 と質問 2 を行った。質問 1 では「東京タワーと認知できるのは画像 1〜9のうちどの画像ですか」と東京タワーと認知できる画像を尋 


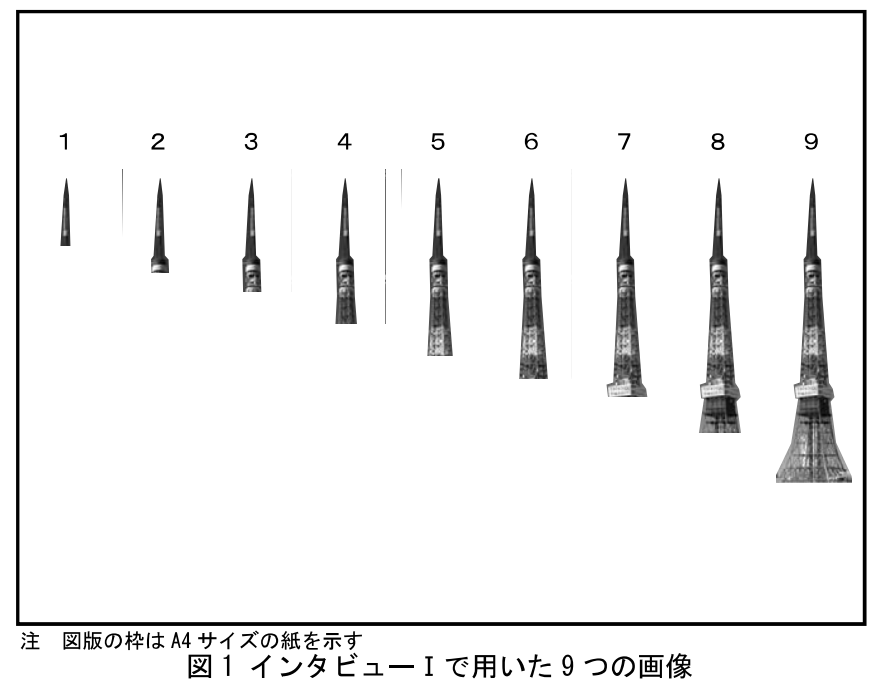

表 2 インタビューI の質問項目

質問 1 東京タワーと認知できるのは、画像 1〜9のうちどの画像ですか。

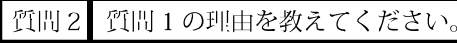

ねた。このとき、回答に迷った被験者には、「1 は東京タワーと認知 できますか」のように、1 から順に各画像について東京タワーと認 知できるか尋ねた。質問 2 では「質問 1 の理由を教えてください」 と質問 1 の理由を自由回答で聞いた。

\section{2 インタビューI I 質問 $1>$ の調査結果}

表 3 にインタビュー調査の結果をまとめた。表 3 の左には質問 1 の結果を示した。質問 1 の結果より、9の画像では 28 人全員 $(100 \%)$ が、 8 の画像では 21 人 $(75.0 \%)$ が、 7 の画像では 17 人 $(60.7 \%)$ と、東京 タワーと認知できると回答した被験者が多くみられた。また、画像 6〜1 の画像では一人も東京タワーと認知できると答えたものはい なかった。

以上の結果から、6 の大展望台上の赤色部分までの画像と、7 の大 展望台までの画像とで東京タワーと認知するか否かがわかれること がわかった。

\section{3 インタビューI I 質問 $2>$ の調査結果}

質問 2 を通して、自由回答により質問 1 の理由を聞いたものを表 3 の右にまとめた。それらを考察すると、東京タワーと認知できる 理由が大きく 3 つに分けられた。表 3 にあるように被験者 28 人中 21 人 $(75.0 \%)$ が「大展望台が見えることに関する理由（理由 1)」、 5 人 $(17.9 \%)$ が「すそ・全部など足元が見えることに関する理由（理 由 2)」、3人 (10.7\%) が「大きさに関する理由（理由 3)」を回答した。

以上より、東京タワーと認知できる見え方は、大きさや足元が見 えることも重要であるが、大展望台まで見えることが最も重要であ ることがわかった。

\section{4 インタビューIの調査方法}

インタビューIの調査結果から、東京タワーと認知できる見え方 には、タワーの大展望台が見えることが重要であると考えられる。 そこで、大展望台が見えると東京タワーと認知できるかをインタ ビューにより調查した。調査は、2014 年 8 月に、東京都大門交差点 にて、インタビューI の被験者とは異なる被験者、成人計 102 人に 対し、個別面接方式で行った。
表 3 インタビューI の調査結果

\begin{tabular}{|c|c|c|c|c|c|c|c|c|c|c|c|c|c|}
\hline \multirow{3}{*}{$\begin{array}{l}\text { 被 } \\
\text { 験 } \\
\text { 者 }\end{array}$} & \multicolumn{9}{|c|}{$\begin{array}{l}\text { 質問1 } \\
\end{array}$} & \multicolumn{4}{|l|}{ 質問2 } \\
\hline & \multicolumn{9}{|c|}{ 東京タワーと認識できる画像 } & \multicolumn{4}{|l|}{ 質問1の理由 } \\
\hline & 1 & 2 & 3 & 4 & 5 & 6 & 7 & 8 & 9 & 自由回答 & 理由1 & 理由2 & 理由3 \\
\hline A & & & & & & & 0 & $O$ & 0 & これ(大展望台)が見えるから & 0 & & \\
\hline$B$ & & & & & & & 0 & $\mathrm{O}$ & 0 & 四角 (大展望台)が見えるから & $\mathrm{O}$ & & \\
\hline C & & & & & & & $\mathrm{O}$ & O & 0 & これ(大展望台)がないとわからない & $\mathrm{O}$ & & \\
\hline $\mathrm{D}$ & & & & & & & $\mathrm{O}$ & $\mathrm{O}$ & $\mathrm{O}$ & ここ(大展望台)があるから & $\mathrm{O}$ & & \\
\hline$E$ & & & & & & & $\mathrm{O}$ & $\mathrm{O}$ & $\mathrm{O}$ & ここ(大展望台)が特徵的だから & $\mathrm{O}$ & & \\
\hline $\mathrm{F}$ & & & & & & & 0 & 0 & 0 & $\begin{array}{l}\text { (大)展望台が見えるとあっち(他の } \\
\text { アンナ)と区斺できるから }\end{array}$ & O & & \\
\hline G & & & & & & & 0 & $\mathrm{O}$ & $\mathrm{O}$ & (大)展望台が見えるから & 0 & & \\
\hline $\mathrm{H}$ & & & & & & & $\mathrm{O}$ & $\mathrm{O}$ & $\mathrm{O}$ & 全体の形がイメージできるから & & & \\
\hline $\mathrm{I}$ & & & & & & & $\mathrm{O}$ & $\mathrm{O}$ & $\mathrm{O}$ & この部分(大展望台)が見えるから & $\mathrm{O}$ & & \\
\hline J & & & & & & & $\mathrm{O}$ & 0 & $\mathrm{O}$ & これ(大展望台)が見えるから & $\mathrm{O}$ & & \\
\hline $\mathrm{K}$ & & & & & & & 0 & 0 & 0 & この部分(大展望台)が重要だから & $\mathrm{O}$ & & \\
\hline$L$ & & & & & & & 0 & 0 & 0 & なんとなくわかるから & & & \\
\hline M & & & & & & & 0 & 0 & 0 & ここら辺(大展望台)が見えるとわか & $\mathrm{O}$ & & \\
\hline $\mathrm{N}$ & & & & & & & 0 & 0 & 0 & ここ(大展望台)まで入っているから & 0 & & \\
\hline 0 & & & & & & & $\mathrm{O}$ & 0 & 0 & ここ(大展望台)まで見えるから & $\mathrm{O}$ & & \\
\hline$P$ & & & & & & & 0 & 0 & 0 & $\begin{array}{l}\text { 大きい部分(大展望台)が見えるか } \\
\text { ら }\end{array}$ & $\mathrm{O}$ & & \\
\hline Q & & & & & & & 0 & 0 & 0 & $\begin{array}{l}\text { これ(大展望台)があるとあっちのア } \\
\text { シテナとなおがうかるから }\end{array}$ & $\mathrm{O}$ & & \\
\hline $\mathrm{R}$ & & & & & & & & $\mathrm{O}$ & 0 & $\begin{array}{l}\text { ここ(大展望台)みえるとよい 全体 } \\
\text { が映っているから }\end{array}$ & O & & \\
\hline $\mathrm{s}$ & & & & & & & & $\mathrm{O}$ & $\mathrm{O}$ & ここ(すそ)が見えるから & & $\mathrm{O}$ & \\
\hline$T$ & & & & & & & & $\mathrm{O}$ & $\mathrm{O}$ & すその方が見えるとわかるから & & $\mathrm{O}$ & \\
\hline $\mathrm{U}$ & & & & & & & & $\mathrm{O}$ & $\mathrm{O}$ & (大)展望台が見えるから & $\mathrm{O}$ & & \\
\hline $\mathrm{V}$ & & & & & & & & & $\mathrm{O}$ & 大きいから & & & $\mathrm{O}$ \\
\hline W & & & & & & & & & $\mathrm{O}$ & 全部が見えるから 大展望台が重要 & 0 & $\mathrm{O}$ & \\
\hline$x$ & & & & & & & & & $\mathrm{O}$ & $\begin{array}{l}\text { 全部が見えるから ここ(大展望台) } \\
\text { が見えるから }\end{array}$ & 0 & 0 & \\
\hline $\mathrm{Y}$ & & & & & & & & & $\mathrm{O}$ & 大きくてこれなら夜景でもわかる & & & $\mathrm{O}$ \\
\hline$Z$ & & & & & & & & & $\mathrm{O}$ & ここ(すそ)が見えるから & & 0 & \\
\hline $\mathrm{AA}$ & & & & & & & & & $\mathrm{O}$ & （他は)中途半端だから & 0 & & \\
\hline $\mathrm{AB}$ & & & & & & & & & $\mathrm{O}$ & $\begin{array}{l}\text { 大きいからここ(大展望台)は見え } \\
\text { て欲しい }\end{array}$ & 0 & & O \\
\hline 人数 & 0 & 0 & 0 & 0 & 0 & 0 & 17 & 21 & 28 & - & 21 & 5 & 3 \\
\hline$\%$ & 0.0 & 0.0 & 0.0 & \begin{tabular}{l|l}
0.0 \\
\end{tabular} & \begin{tabular}{|l|l|}
0.0 \\
\end{tabular} & 0.0 & 60.7 & 75.0 & 100 & - & 75.0 & 17.9 & 10.7 \\
\hline 理由 & & 「大层 & & 台」t & 光 & & ること। & 下関 & する玨 & & & & \\
\hline $\begin{array}{l}\text { 理由 } \\
\text { 理由 }\end{array}$ & & & & & & & 由 & & & にに関する理由 & & & \\
\hline
\end{tabular}

調査方法は、東京タワーの大展望台までが映っている画像（表 4) をみせ、「この画像は東京タワーと認知できますか、『はい』か『い いえ』でお答えください」と尋ねた。この画像は、インタビューI の画像 7 と同じものである。表 4 に示した調査結果は、面接者であ る筆者が回答を記入し、インタビュー終了後に集計したものである。

さらに、102人に対する標本調査で、「はい」と答えた人の割合を 用いて母比率の Z 推定を行い注5)、東京タワーの大展望台が見えると きの認知できる度合と認知できない度合いを信頼度 $99 \%$ で推定した。

\section{5 インタビューIの調査結果}

インタビューII の結果を表 4 に示した。 84 人が「はい」と、18 人が「い いえ」と答えた。つまり、東京タワーの大展望台までが映っている 画像では、8割以上の人が東京タワーと認知できることがわかった。

そこで、「はい」と答えた人の割合を用いて母比率の Z 推定を行っ たところ、信頼度 $99 \%$ で、東京タワーの大展望台が見えるときの認 知できる度合は、 $72.6 \%$ から $92.1 \%$ の間にあるといえる。また、東 京タワーの大展望台が見えるときの認知できない度合は、7.9\%から 27. $4 \%$ の間にあるといえる。つまり、東京タワーの大展望台が見え ると東京タワーであると認知できるといえる。

\section{6 インタビューIII調査方法}

インタビューII の調査結果からでは、大展望台が見えないときに も認知できる可能性は棄却できない。そこで、大展望台が見えない 
と東京タワーと認知できないかをインタビューにより調査すること とした。調查は、2014 年 8 月に、東京都大門交差点にて、インタビュー I 、II の被験者とは異なる被験者、成人計 100 人に対し、個別面接 方式で行った。

調査方法は、東京タワーの大展望台以下が映っていないの画像（表 5）をみせ、「この画像は東京タワーと認知できますか、『はい』か『い いえ』でお答えください」と尋㸚た。この画像は、インタビューI

表 4 インタビューIIで用いた画像と調査結果

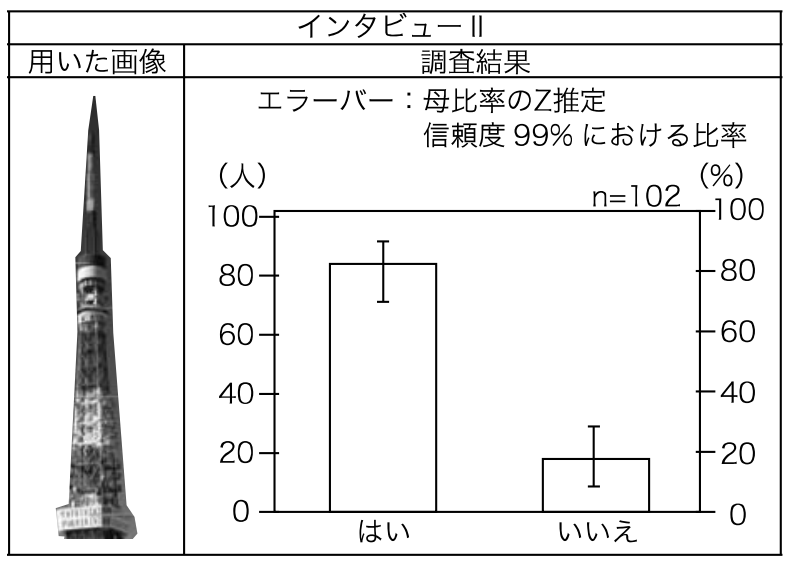

表 5 インタビュー正で用いた画像と調査結果

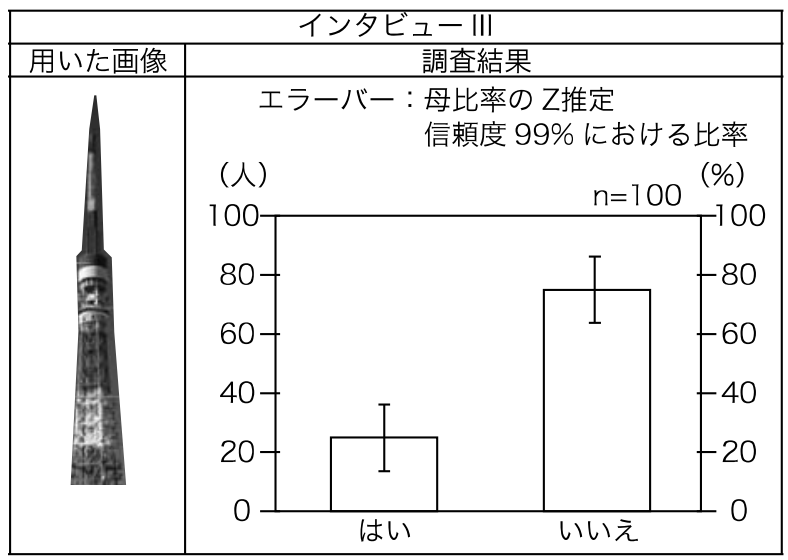

表 6 認知域と不認知域の物理的定義と事例

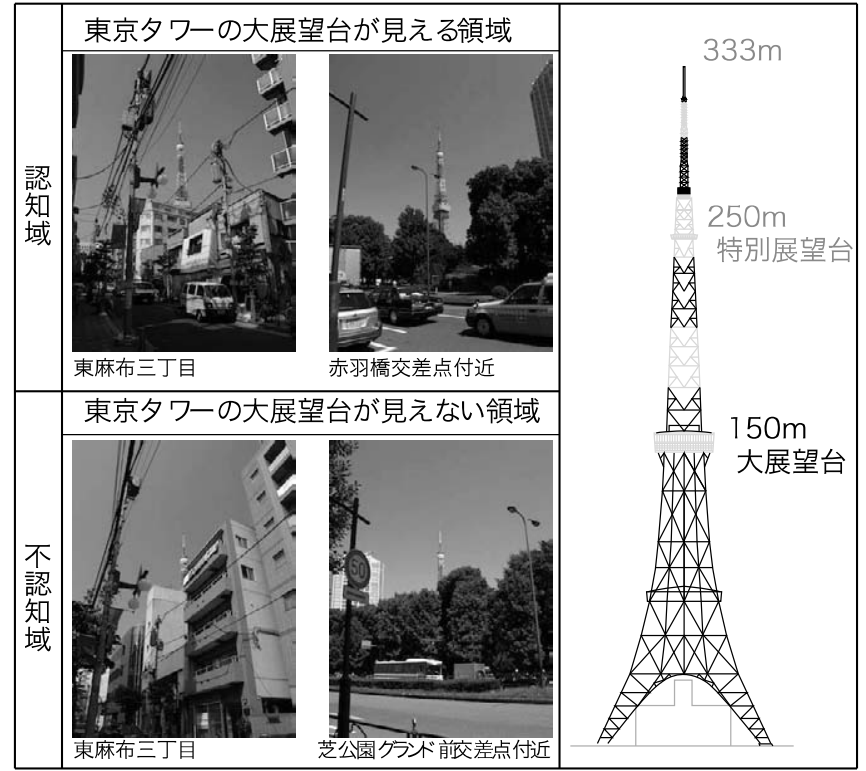

の画像 6 と同じものである。表 5 に示した調査結果は、面接者であ る筆者が回答を記入し、インタビュー終了後に集計したものである。

さらに、100人に対する標本調査で、「いいえ」と答えた人の割合 を用いて母比率の Z 推定を行い、東京タワーの大展望台が見えない ときの認知できる度合いと認知できない度合を信頼度 $99 \%$ で推定し た。

\section{7 インタビュー正の調査結果}

インタビューIIIの結果を表 5 に示した。2 5 人が「はい」と、75人 が「いいえ」と答えた。つまり、東京タワーの大展望台以下が映っ ていないの画像では、7 割以上の人が東京タワーと認知できないこ とがわかった。

そこで、「いいえ」と答えた人の割合を用いて母比率の Z 推定を 行ったところ、信頼度 $99 \%$ で、東京タワーの大展望台が見えないと きの認知できる度合いは、13.8\%から $36.2 \%$ の間であるといえる。 また、東京タワーの大展望台が見えないときの認知できない度合は、 63. $8 \%$ から $86.2 \%$ の間にあるといえる。つまり、東京タワーの大展 望台が見えないと東京タワーであると認知できないといえる。

\section{8 認知域と不認知域の物理的定義}

東京タワーの「可視域」は、東京タワーと認知できる「認知域」 と認知できない「不認知域」に区別できる。インタビューI～III の 結果より、東京タワーの大展望台が見えると東京タワーと認知でき、 大展望台が見えないと東京タワーと認知できないといえる。

そこで本稿では、東京タワーの大展望台が見える領域を「認知域」、 東京タワーは見えるが大展望台は見えない領域を「不認知域」と定 義した（表6）。

\section{3 東京タワーの可視域}

本章では、東京タワーの実際の見え方を周辺の街路から隈なく調 查し、さらに東京タワーの可視域である街路と視距離との関係を定 量的に考察する。

\section{1 調査地域}

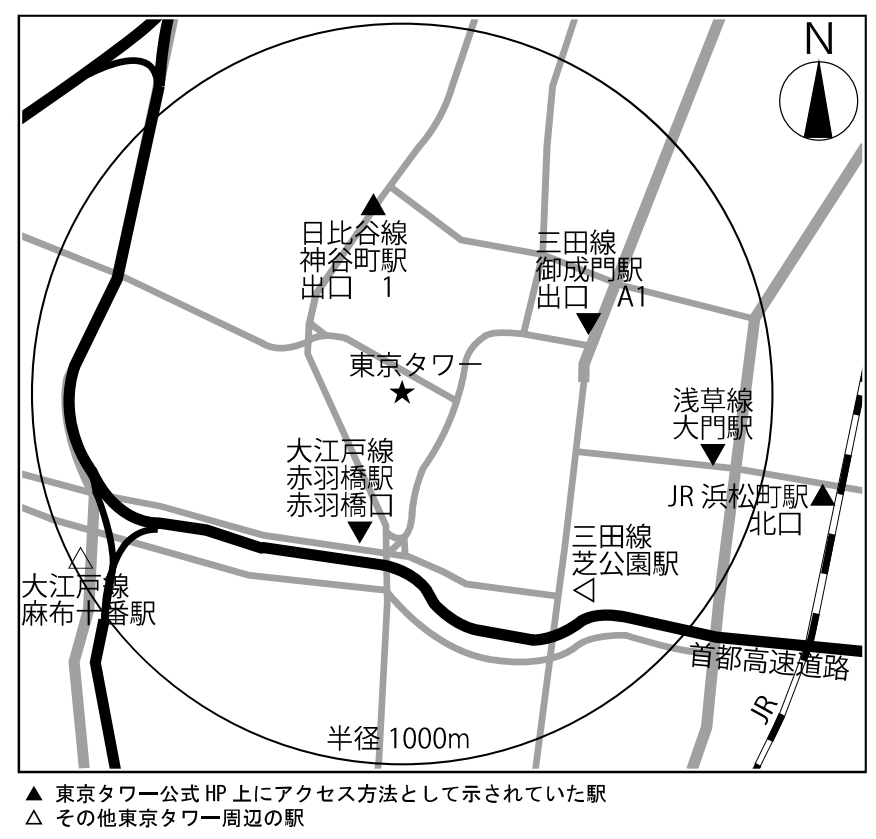

図 2 東京タワーの最寄り駅と調査範囲の関係 
東京タワーの可視域・認知域を検証するにあたり、東京タワー来 場者が公共交通機関を利用する際の最寄り駅からの歩行経路を考慮 し、対象範囲を検討した。

東京タワーの公式ホームページには、東京タワーのアクセス方法 として、公共交通機関を利用した場合の最寄りの地下鉄の駅、JRの 駅、バスの停留所が挙げられている。 地下鉄の駅では、大江戸線赤羽橋駅 ( 徒歩 5 分、以下徒歩略)、日比谷線 神谷町駅 (7 分)、三田線御成門駅 (6 分)、浅草線大門駅 (10 分)、JR の駅 では JR 浜松町駅（15 分）が挙げら れ、バスの停留所では、都営バス東 京タワー停留所 (1 分)、都営バス虎 八門五丁目（東京タワー入口）停留 所 (3 分)、東急バス東京タワー停留 所（1 分）が挙げられている。また、 $J R$ 浜松町駅北口からは東京タワー行 きのバスも出ており、敷地の東側に ある東京タワー ( 終点) 停留所 (0 分) も挙げられている。このことから、 JR 線からの東京タワーへのアクセス は、浜松町駅からバスを利用するも のと考えられる。

図 2 では、東京タワーとこれらの 最寄り駅との位置関係を示した。東 京タワーから浜松町駅が最も遠くお よそ $1200 \mathrm{~m}$ 、大門駅およそ 950m、御 成門駅およそ $600 \mathrm{~m}$ 、神谷町駅およそ 500m、赤羽橋駅およそ $450 \mathrm{~m}$ に位置 することがわかる。また、公式ホー ムページには掲載されていなかった が、東京タワーから浜松町駅より近 い駅として、三田線芝公園駅およそ $600 \mathrm{~m}$ 、南北線麻布十番駅およそ $850 \mathrm{~m}$ も挙げられる。バス利用が示されて いる浜松町駅を除くと、これらの中 で最も遠い駅は東京タワーからおよ そ950m 離れた大門駅であった。

以上から、東京タワーの徒歩圈は、 東京タワーから半径 $1000 \mathrm{~m}$ くらいで あると考えられ、対象範囲は、東京 タワーから半径 $1000 \mathrm{~m}$ 以内とした。

\section{2 調査日時と調査方法}

既往のランドマークの可視域の研 究においては、幹線道路に着目され ることが多いが、本研究では一般道 路を隈なく、歩行者専用道路（以下、 歩道) から調查を行った。

まず、東京タワー周辺半径 $1000 \mathrm{~m}$ 以内にある一般道路を抽出した。そ

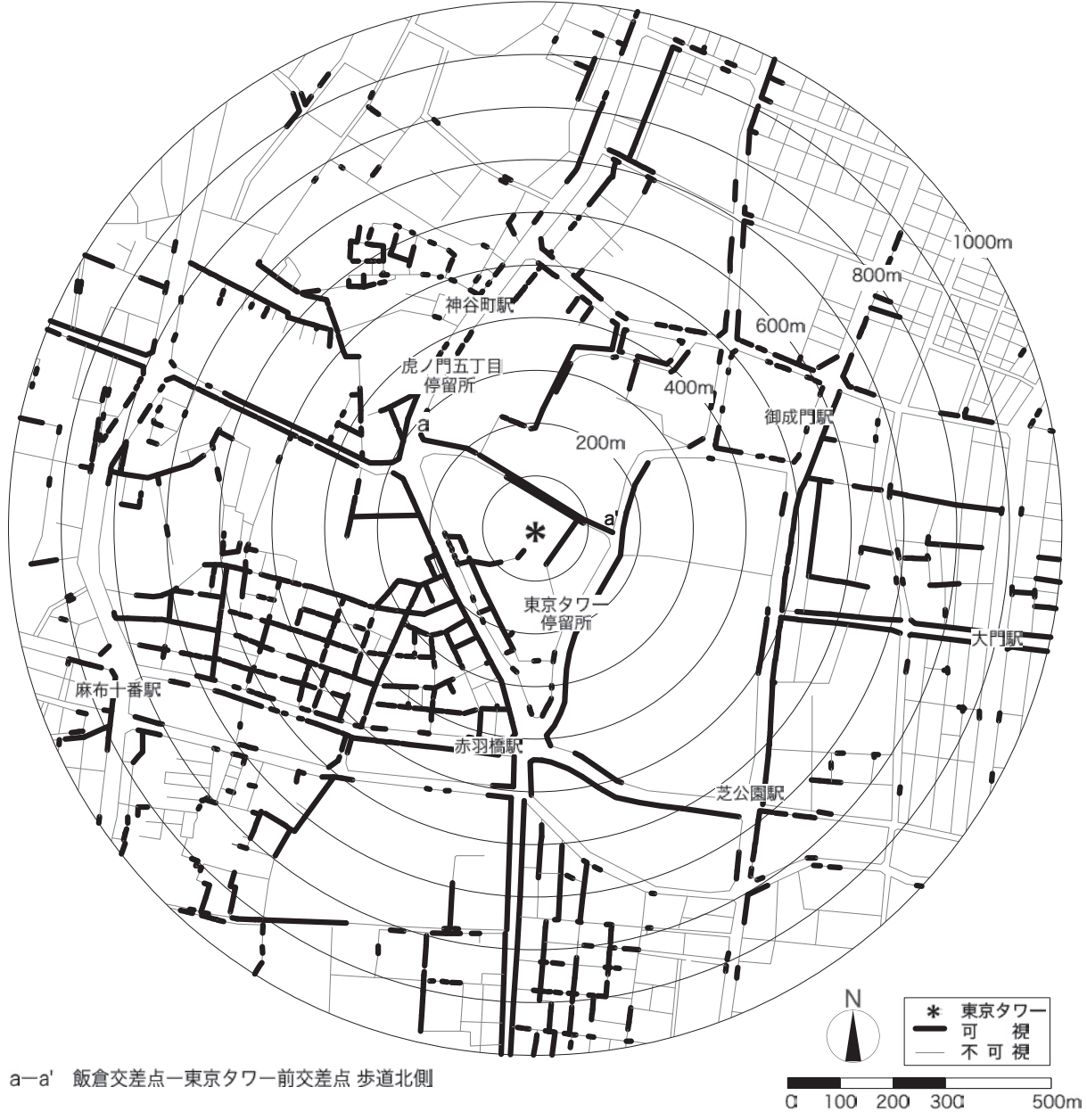

図 3 東京タワーの周辺街路における可視域

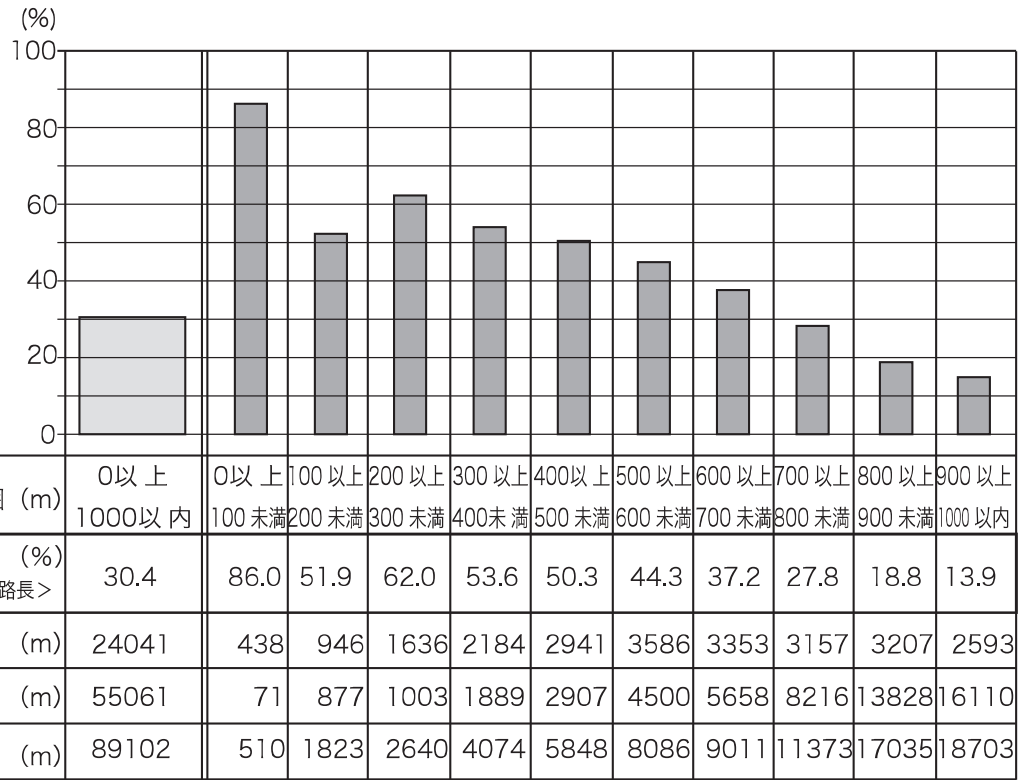

図 4 東京タワーの周辺街路における可視域の割合 
調査は、2005 年 7 月 15 日から 9 月 29 日の間に、東京タワーを中 心とした半径 $1000 \mathrm{~m}$ 以内にある街路からの見え方の変化を目視によ り確認する方法で行った。その際、写真撮影も行った。写真は、目 線の高さ（高さ $1.4 \mathrm{~m}$ ) から、東京タワーが写真の中央にくるよう撮 影した。写真は 1334 枚となった。また、対象とした街路は延べ $89 \mathrm{~km}$ となった。

\section{3 視距離の設定}

視距離の範囲は東京タワーから 0 以上 $100 \mathrm{~m}$ 未満、100 以上 $200 \mathrm{~m}$ 未満、 $200 \mathrm{~m}$ 以上 $300 \mathrm{~m}$ 未満、300 以上 $400 \mathrm{~m}$ 未満、 $400 \mathrm{~m}$ 以上 $500 \mathrm{~m}$ 未 満、 $500 \mathrm{~m}$ 以上 $600 \mathrm{~m}$ 未満、 $600 \mathrm{~m}$ 以上 $700 \mathrm{~m}$ 未満、 $700 \mathrm{~m}$ 以上 $800 \mathrm{~m}$ 未満、 $800 \mathrm{~m}$ 以上 $900 \mathrm{~m}$ 未満、 $900 \mathrm{~m}$ 以上 $1000 \mathrm{~m}$ 以下の範囲にわけた。

\section{4 可視域 $\cdot$ 不可視域の設定と可視割合の求め方}

東京タワーが少しでも見える場所を可視域、全く見えない場所を 不可視域とした。さらに、東京タワーまでの距離と可視域との関係 を把握するために、視距離の範囲と可視割合を以下のように定めた。 可視域の街路の割合は、（式 1）に示すように可視域の街路の長さ の合計と対象の範囲の全街路の長さの商により求めた。

$\{$ 可視域の街路の割合 $\}=\{$ 可視域の街路の合計 $\} /\{$ 対象の全街路長 $\}$ $\cdots$ (式 1)

\section{5 東京タワーの可視域の考察}

図 3 では、地図上に東京タワーの可視域である街路を表記した。 太線は東京タワーの可視域、細線は不可視域を示している。図 4 では、 東京タワーの視距離の範囲ごとの可視域である街路の割合を示して いる。

半径 $1000 \mathrm{~m}$ の範囲の街路のうち、東京タワーの可視域は $30.4 \%$ 、 不可視域は $69.6 \%$ となっていた。このことから、東京タワーの周辺 $1000 \mathrm{~m}$ の範囲において東京タワーが見える街路と見えない街路の割 合はおおよそ1:2になっており、東京タワーが見えない街路の方が 多くなっていることがわかる。

また、視距離と可視域である街路の割合の関係ついてであるが、 $0 \mathrm{~m}$ 以上 $100 \mathrm{~m}$ 末満では $86.0 \%$ であり、そのほとんどの街路で東京夕 ワーが見ることができる。100 以上 $200 \mathrm{~m}$ 未満では $51.9 \% 、 200 \mathrm{~m}$ 以 上 $300 \mathrm{~m}$ 未満では $62.0 \%$ 、300m 以上 $400 \mathrm{~m}$ 未満では $53.6 \%$ 、 $400 \mathrm{~m}$ 以 上 $500 \mathrm{~m}$ 未満では $50.3 \%$ と、東京タワーから $500 \mathrm{~m}$ 未満の範囲では過 半の街路において東京タワーが見ることができる。さらに $500 \mathrm{~m}$ 以上 $600 \mathrm{~m}$ 未満では $44.3 \% 、 600 \mathrm{~m}$ 以上 $700 \mathrm{~m}$ 未満では $37.2 \% 、 700 \mathrm{~m}$ 以上 $800 \mathrm{~m}$ 未満では $27.8 \% 、 800 \mathrm{~m}$ 以上 $900 \mathrm{~m}$ 未満では $18.8 \%$ 、900m 以上 $1000 \mathrm{~m}$ 以下では $13.9 \%$ となっており、タワーから $100 \mathrm{~m}$ 以上 $200 \mathrm{~m}$ 未 満の範囲で可視域が微増するものの、東京タワーから離れるほど可 視域が減少している。また、図 3 から、a-a'（飯倉交差点一東京タワー 前交差点 歩道北側）のように $100 \mathrm{~m}$ 以上連続して可視域となってい る場所が、東京タワーの周辺街路で多くみられることがわかる。

このように、東京タワーから離れるほどタワーが見えなくなって いることを定量的に示した。可視域の割合は視距離に対して比例し て減少していた。また、東京タワーは周辺半径 $500 \mathrm{~m}$ 未満では東京夕 ワーが見えない街路より見える街路の方が多いが、範囲を広げ半径 $1000 \mathrm{~m}$ 以内では東京タワーが見える街路より見えない街路の方が多 くなっていることがわかった。さらに、東京タワーは周辺街路にお いて連続的に見えることがわかった。

\section{4 東京タワーの認知域}

本章では、東京タワーの大展望台が見える領域を「認知域」と定 義し、認知域を地図上に表記し、認知域である街路と視距離との関 係を定量的に考察寸る。

\section{1 認知域の設定と認知域の街路の割合の求め方}

2 章において、東京タワーと認知寸るには、大展望台までが見え ることが重要であると結論づいたため、東京タワーの大展望台まで が見える領域を認知域とした。

認知域の街路の割合は、（式 2）で示すように認知域の街路の長さ の合計と対象の範囲の全街路の長さの商により求めた。

$\{$ 認知域の街路の割合 $\}=\{$ 認知域の街路の合計 $\} /\{$ 対象の全街路長 $\}$

\section{2 東京タワーの認知域の考察}

図 5 では、地図上に東京タワーの認知域である街路を表記した。 太線は東京タワーの認知域、細線はその他の対象範囲の街路を示し ている。図6では、東京タワーまでの距離ごとの認知である街路の 割合を示している。

半径 $1000 \mathrm{~m}$ の範囲の街路のうち、東京タワーの認知域は $10.7 \%$ 、 となっていた。このことから、東京タワーの周辺 $1000 \mathrm{~m} の$ 範囲にお いて東京タワーが認知できる街路が非常に少ないことがわかる。

また、視距離と認知域である街路の割合の関係ついてであるが、 $0 \mathrm{~m}$ 以上 $100 \mathrm{~m}$ 未満では $86.0 \%$ であり、そのほとんどの街路で東京夕 ワーが認知できる。 $100 \mathrm{~m}$ 以上 $200 \mathrm{~m}$ 未満では $46.5 \%$ と急激に減少し 半数以上の街路で東京タワーと認知できなくなる。 $200 \mathrm{~m}$ 以上 $300 \mathrm{~m}$ 未満ではさらに減少し $30.7 \%$ 、300m 以上 $400 \mathrm{~m}$ 未満では $16.8 \%$ 、 $400 \mathrm{~m}$ 以上 $500 \mathrm{~m}$ 未満では $14.4 \% 、 500 \mathrm{~m}$ 以上 $600 \mathrm{~m}$ 未満では $14.0 \%$ 、 $600 \mathrm{~m}$ 以上 $700 \mathrm{~m}$ 未満では $13.4 \%$ と $300 \mathrm{~m}$ 以上 $700 \mathrm{~m}$ 未満の範囲では $15 \%$ 前後となる。 $700 \mathrm{~m}$ 以上 $800 \mathrm{~m}$ 末満では $7.5 \%$ 、 $800 \mathrm{~m}$ 以上 $900 \mathrm{~m}$ 末 満では $5.5 \%$ 、900 $\mathrm{m}$ 以上 $1000 \mathrm{~m}$ 未満では $3.6 \%$ と徐々に小さくなっ ていることがわかる。次に、図 5 から認知域の連続性を読み解くと、 $100 \mathrm{~m}$ 以上連続して認知域となっている場所は、17 箇所と可視域に比 べると明らかに少なくなっている。うち、a-a'（飯倉交差点一東京夕 ワ一前交差点 歩道北側)、 $\mathrm{b}^{-} \mathrm{b}^{\prime}$ (東京タワ一敷地北側 歩道南側）、 d-d'（東京タワー敷地東側街路）、 $\mathrm{e}^{-} \mathrm{e}^{\prime}$ （都道 301 号 東京タワー交 差点手前一赤羽橋交差点 歩道西側)、1-1'（東京タワースタジオ敷 地西側街路)、m-m'（桜田通り東麻布一丁目交差点から北 歩道東側） は東京タワーから $200 \mathrm{~m}$ 以内の街路、またはその延長である。また、 e-e' (都道 301 号 東京タワー交差点手前一赤羽橋交差点 歩道西側)、 h-h'（桜田通り赤羽橋交差点一三田一丁目交差点 歩道東側）、 $\mathrm{i}-\mathrm{i}$ ' （桜田通り赤羽橋交差点一三田一丁目交差点 歩道西側）、 $\mathrm{k}^{-} \mathrm{k}^{\prime}$ （中之 橋交差点から南 街路)、O-o'（外苑東通り板倉交差点から西 歩道北 側）、p-p’（外苑東通り片町交差点から西 歩道南側）、 q-q'（外苑東 通り片町交差点から西 歩道北側）は東京タワーに対し南から西北西 に位置するタワーを中心とした放射線上の街路である。

このようにみてみると、東京タワーからの距離に対して認知域が 減少していることを定量的に示すことで、認知域の割合は視距離に 対して反比例していると言えることがわかった。また、過半の部分 が含まれるのは東京タワーから $200 \mathrm{~m}$ ほどまでであり、200 $\mathrm{m}$ 以上 400m 未満になると急激に少なくなっていることがわかった。さらに、 
東京タワーは周辺街路において、連 続的に認知できる場所は少なく、そ のほとんどがタワーの足元かタワー の南から西北西に位置するタワーを 中心とした放射線上であった。

\section{5 東京タワーの不認知域}

4 章の結果から、東京タワーの認知 域は少なく、東京タワーの一部分し か見えずそれが東京タワーであると 認知できない場所が多いことがわか る。本章では、このような東京タワー は見えるが大展望台は見えない領域 を「不認知域」と定義し、地図上に 表記し、不認知域である街路と視距 離との関係を定量的に考察する。

\section{1 不認知域の設定と不認知域の街} 路の割合の求め方

2 章に扔いて、東京タワーと認知寸 るには、大展望台までが見えること が重要であると結論づいたため、東 京タワーは見えるが大展望台は見え ない領域を不認知域とした。ゆえに、 可視域から認知域を除くことで示し た不認知域と設定した（式 3 )。

$\{$ 不認知域 $\}=\{$ 可視域 $\}-\{$ 認知域 $\}$

また、不認知域の街路の割合は、(式

4）で示すように不認知域の街路の長 さの合計と可視域である街路の長さ の合計の商により求めた。

\{不認知域の街路の割合 $\}$

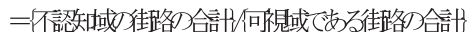

\section{2 東京タワーの不認知域の考察}

図 7 は、不認知域である街路を地 図上に示したものである。図8では、 東京タワーまでの距離ごとの不認知 域である街路の割合を示している。

$0 \mathrm{~m}$ 以上 $100 \mathrm{~m}$ 未満の範囲において 東京タワーの可視域と認知域は同じ であるため不認知域は $0 \%$ である。 $100 \mathrm{~m}$ 以上 $200 \mathrm{~m}$ 未満の範囲において は $10.4 \%$ と増加する。 $200 \mathrm{~m}$ 以上 $300 \mathrm{~m}$ 未満の範囲になると $50.5 \%$ と急激 に増加し、300m 以上 $400 \mathrm{~m}$ 未満では $68.7 \%$ と微増し、 $400 \mathrm{~m}$ 以上 $500 \mathrm{~m}$ 未満 では $71.4 \% 、 500 \mathrm{~m}$ 以上 $600 \mathrm{~m}$ 未満で

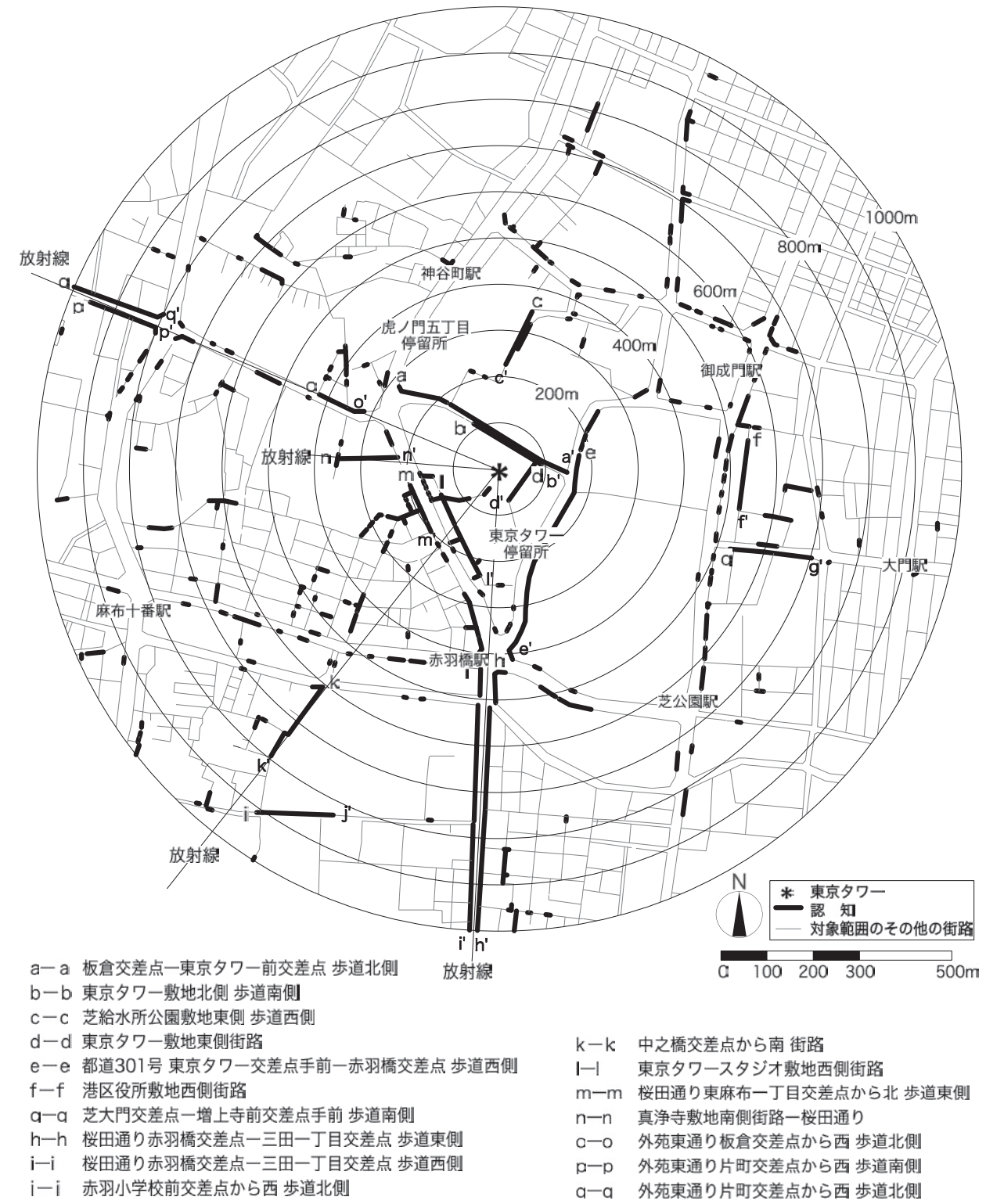

図 5 東京タワーの周辺街路における認知域

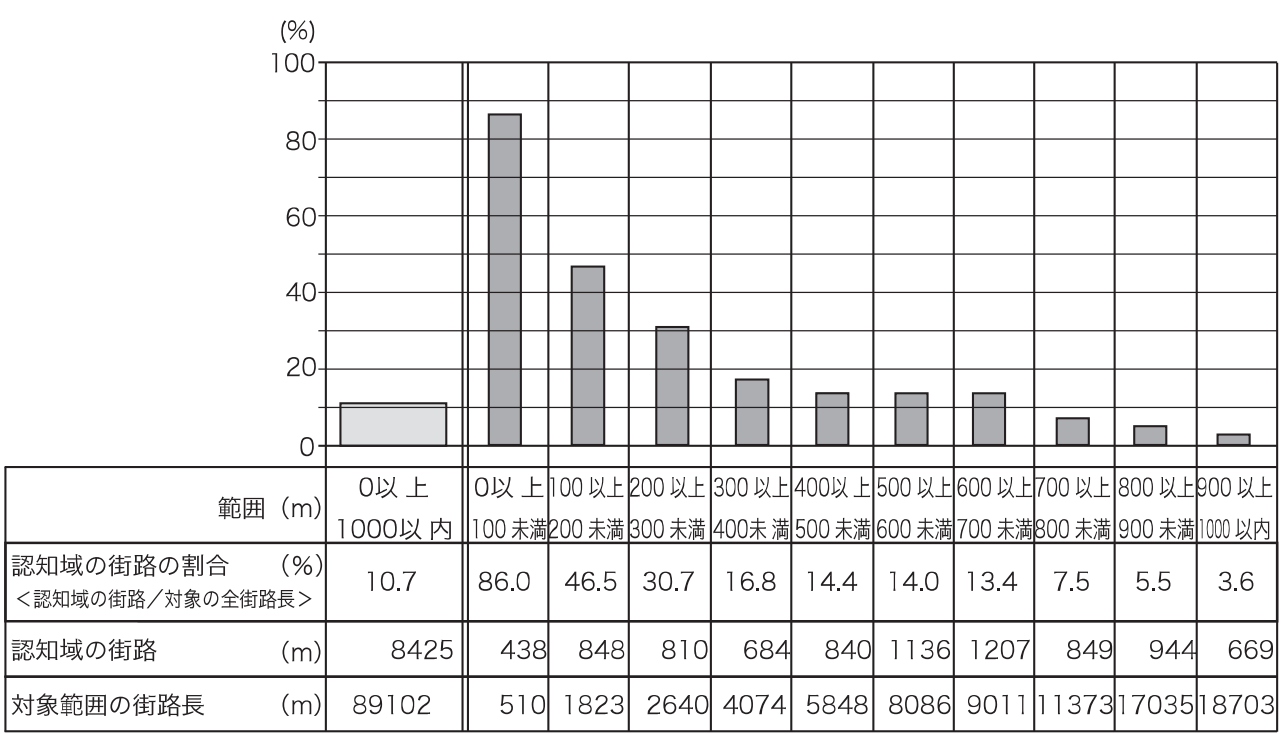

図 6 東京タワーの周辺街路における認知域の割合 
は $68.3 \% 、 700 \mathrm{~m}$ 以上 $800 \mathrm{~m}$ 未満では $73.1 \% 、 800 \mathrm{~m}$ 以上 $900 \mathrm{~m}$ 未満で は $70.6 \% 、 900 \mathrm{~m}$ 以上 $1000 \mathrm{~m}$ 未満では $74.2 \%$ 之、 $200 \mathrm{~m}$ 以上 $1000 \mathrm{~m}$ 未 満の範囲では 5 割は超えている。以上より、東京タワーからの距離 が $200 \mathrm{~m}$ 以上になると不認知域が多くなっていることがわかった。つ まり、東京タワーから $200 \mathrm{~m}$ 以上離れたところでは例え東京タワーが
見えたとしても、その半数以上が東京タワーとはわからない。

言い換えると、東京タワーは、 $200 \mathrm{~m}$ 以上離れたところでは夕ワー の上部しか見えずそれが東京タワーであるとはわからない。つまり、 東京タワーは $200 \mathrm{~m}$ 未満の近距離において認知されるランドマークで あると結論づけられる。

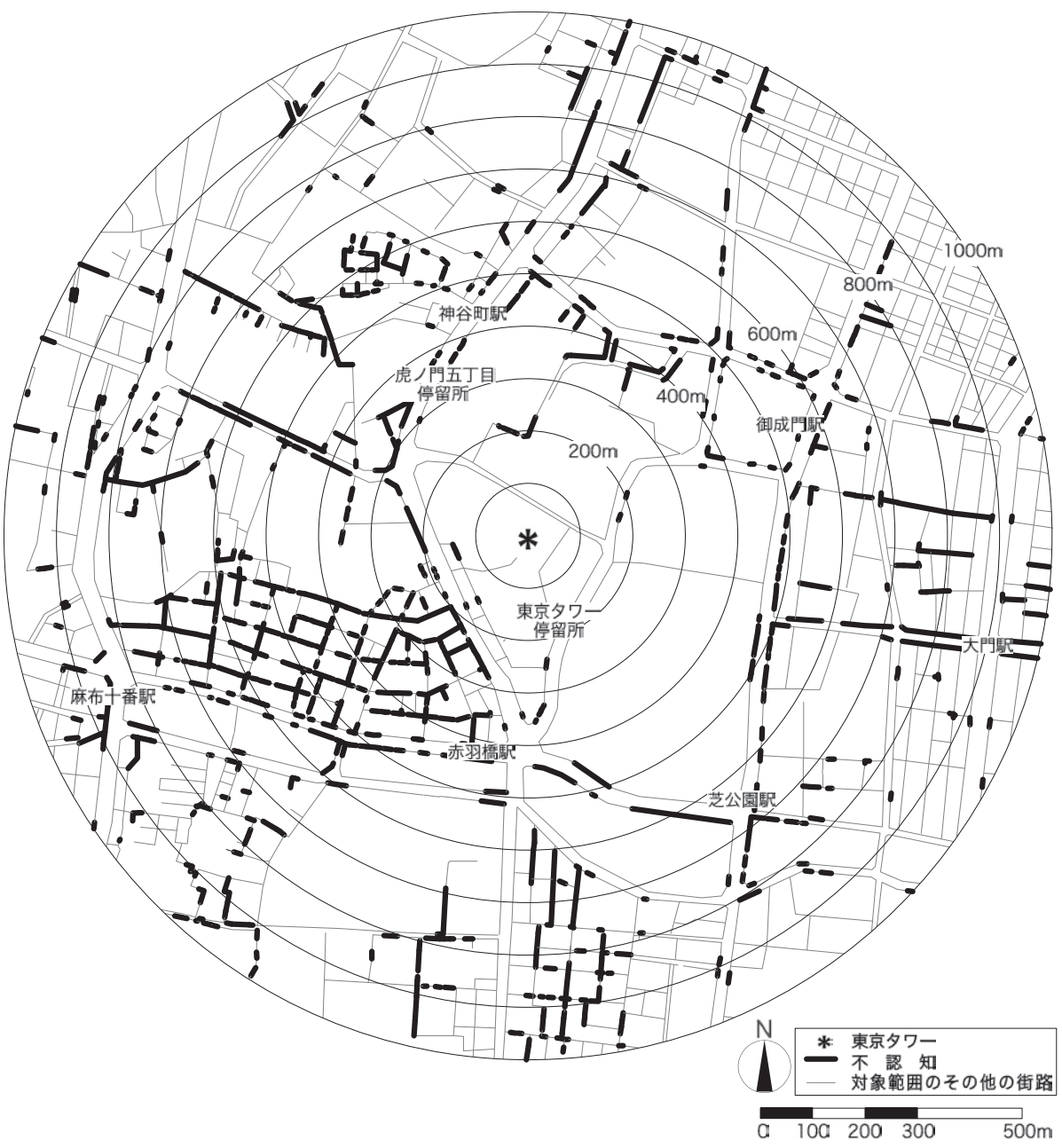

図 7 東京タワーの周辺街路における不認知域

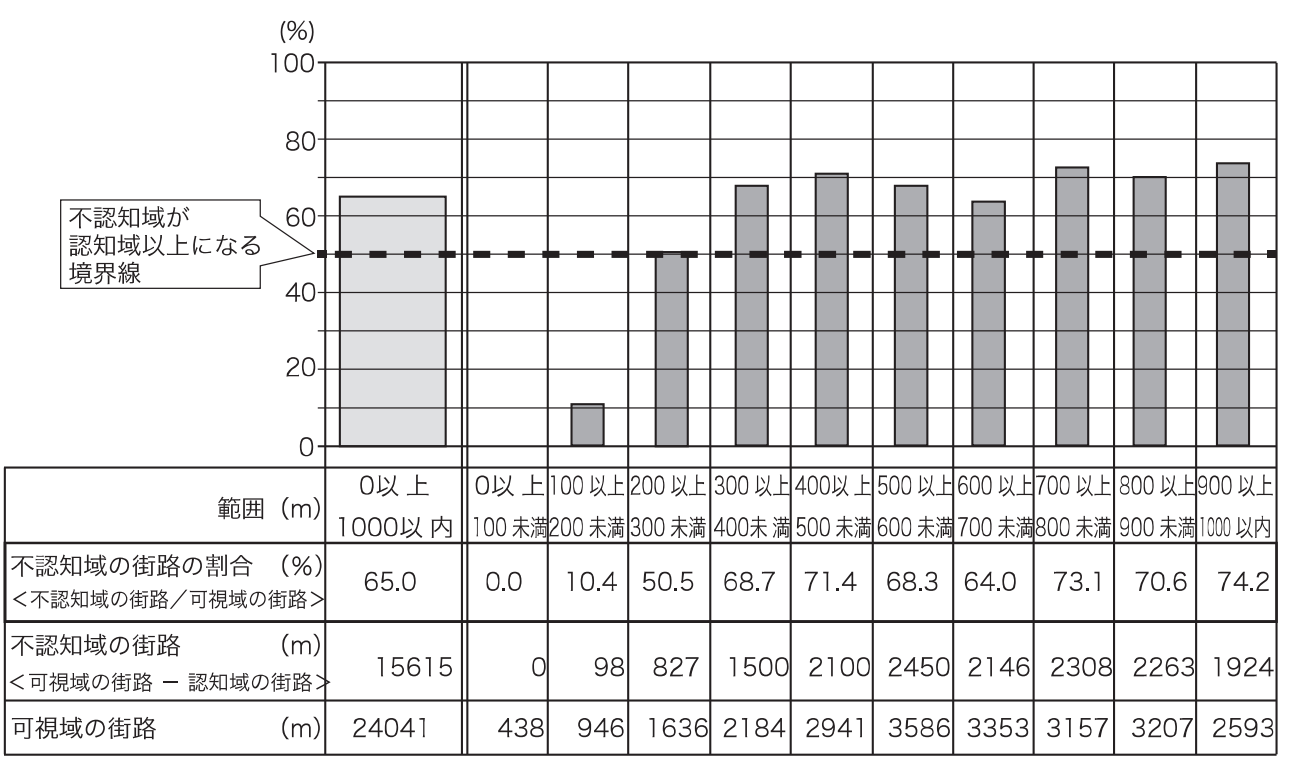

図 8 東京タワーの周辺街路における不認知域の割合
6 結

本稿では、東京タワーの周辺街路 から見える「可視域」を、東京タワー と認知できる「認知域」と認知でき ない「不認知域」に区別し実証的か つ定量的に検証することで、東京夕 ワーの見える場所と認知できる場所 を明らかにした。

まず、 2 章では、インタビュー調 查から、東京タワーの認知できる見 え方は、地上 $150 \mathrm{~m}$ の高さにある大 展望台が見える見え方であることを 確認した。そこで、本稿では、東 京タワーの大展望台が見える領域を 「認知域」、東京タワーは見えるが大 展望台は見えない領域を「不認知域」 と定義した。

次に数量的に捉えた 3 章では、東 京タワー周辺半径 $1000 \mathrm{~m}$ の範囲にお いて可視域・不可視域である街路を 実証的に考察することで、東京夕 ワーが見える街路と見えない街路の 比は $1: 2$ となっており、半径 $1000 \mathrm{~m}$ の範囲において街路上では東京夕 ワーの見える場所は少なく、見えな い場所の方が多いことがわかった。

さらに 4 章では、認知域を同様 に考察することで、東京タワーの認 知性は視距離に反比例することがわ かった。また、半径 $1000 \mathrm{~m}$ の範囲に おいて街路上では東京タワーの認知 域は少なく、認識できる場所が少な いことがわかった。また、認知域は 特定の街路において連続的にみられ た。ここでいう特定の街路とは、タ ワーから $200 \mathrm{~m}$ 未満の街路かその延長 上の街路、またはタワーに対し南か ら西北西にあるタワーを中心とした 放射線上の街路である。このような 特定の街路は、東京タワーの認知で きる場所である。

そこで 5 章では、不認知域を考察 し、東京タワーは $200 \mathrm{~m}$ 以上離れたと ころでは見ることができるもののそ 
れと認知することは難しいことがわかった。つまり、東京タワーは $200 \mathrm{~m}$ 未満の近距離にて認知できるランドマークであるといえる。

これらの結果から、仮に、東京タワーの頂部に何か新しいデザイ ンがされたと寸れば、本稿で得られた東京タワーの不認知域の一部 は認知域となり、東京タワーの認知できる場所は多くなることがわ かる。あるいは、頂部に特徵のあるライトアップがなされれば、東 京タワーと認知できる場所が多くなる。このように、ランドマーク と認知できる見え方は、その建造物ごとに異なると考えられ、その ランドマークの認知域を広めることができよう。

さらに本稿では、東京タワーを可視域だけでなく認知域の考察す ることで、東京タワーが放射状に参照されていることを示すことが できた。桐敷は、江戸時代の街路計画について、山获や丘陵を目標 とする基準線を配置した計画であり、東京タワーの敷地である芝丘 陵地も目標とした丘陵の一つであると述べている。このことから、 東京タワーが放射状に参照されているのは、東京タワーの敷地が街 路構造と密接な関倸にあるためと推測される。東京タワーの敷地之 街路構造の具体的な検証は今後の課題としたい。また、本稿では、 東京タワーと視距離との考察による全体の傾向を理解するにとどま り、街路ごとの考察までは至らなかった。今後は、街路ごとの移動 パターンの観点からの東京タワーの可視域・認知域・不認知域の検 証を行う必要がある。

\section{謝辞}

東京電波塔株式会社の方に対し情報提供をして頂き、心からお礼 申しあげます。また、インタビューに協力してくださった方々に深 く感謝致します。

\section{注}

注 1) ランドマークを眺める場所を「視点場」と呼ぶ。

注 2）正式名称は、日本電波塔である。東京タワーの略歴を以下に示す。 参照 : 参考文献 19) pp. 106-109

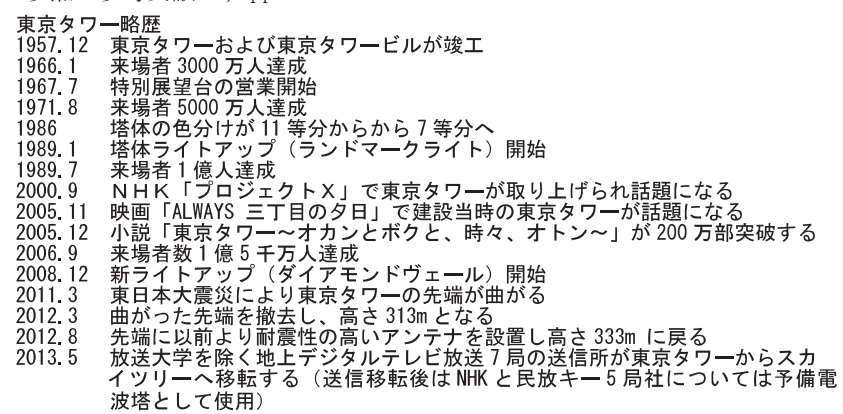

注 3）社会的な意味、機能、歴史、名称などによりもより認知性に影響を与え ると考えられるが、参考文献 16) p. 55 を参考に、本稿の検証では、視覚的 に認知できる物体がもたらす効果のみを対象としている。

注 4) 参考文献 18) p. 189

注 5）参考文献 21)pp. 179-180 母比率の Z 推定は、サンプルサイズが $\mathrm{n} \geqq 30$ のときに $\mathrm{z}$ 分布を活用して、標本比率 $\mathrm{p}$ から母比率 $\mathrm{P}$ を推定するときに使う。

\section{参考文献}

1）西村幸夫十街並み研究会: 都市の風景計画 欧米の景観コントロール 手法 と実際，学芸出版社，2000

2）東京都景観計画 2011 年 4 月改訂

http://www. toshiseibi. metro. tokyo. jp/kenchiku/keikan/keikaku. pdf, (参照 2011. 10.01)

3）小林隆史，大澤義明：都市中心地区ランドマークの可視性に関する研究， 日本建築学会計画系論文集，第 583 号, pp. 91-98, 2004.9

4) 岡田昌彰 : テクノスケープ 同化と異化の景観論, 景観学研究叢書, 2003
5）中井邦夫, 坂本一成, 伊庭野大輔, 足立真, 安森亮雄, 久野靖広, 遠藤康一: 超高層建築の可視領域と見え方, ランドマークとしての超高層建築が形成 する地域的領域 1, 日本建築学会大会学術講演梗概集 F-2, pp. 679-680, 2006. 7

6）伊庭野大輔, 坂本一成, 中井邦夫, 足立真, 安森亮雄, 久野靖広, 遠藤康 一：可視領域と視点の連続による領域的特徴,ランドマークとしての超高 層建築が形成する地域的領域 2, 日本建築学会大会学術講演梗概集 F-2, pp. $681-68,2006.7$

7）大竹由夏，鵜沢隆：都市空間におけるランドマークの見え方に関する研究， 一事例「東京タワー」の街路からの見え方とその変化一, 日本建築学会大 会学術講演梗概集 F-2，pp. 677-678，2006.7

8）大竹由夏，鵜沢隆：都市空間におけるランドマークの見え方に関する研究 2, 東京タワー、名古屋テレビ塔、京都タワー、通天閣の周辺街路からの 見え方とその変化, 日本建築学会大会学術講演梗概集 F-2, pp. 693-694, 2008. 7

9）芦原義信 : 街並みの美学, 岩波書店, 1979

10) 西村幸夫: 西村幸夫 風景論ノート 景観法・町並み・再生, 鹿島出版会, 2008

11）桐敷真次郎：都市の成立とその歴史的展開，4. 近代都市の形成（その 1)東京の都市史・都市計画史的研究一, 都市研究報告第 5 号, 東京都立大学 都市研究委員会, 1971

12）槙文彦，若月幸敏，大野秀敏，高谷時彦：見えがくれする都市，鹿島出版 会, 1980

13) 松本直司，寺西敦敏，仙田満：街路景観の乱雑・整然性要因に関する研究 , 中心市街地における乱雑・整然性に関する研究 その 1 , 日本建築学会計 画系論文報告集，第 429 号, pp. 73-82, 1991. 11

14) 松本直司, 高井智代 : 個人差をふまえた街路景観の乱雑・整然性および魅 力度の関連, 中心市街地における乱雑・整然性に関する研究その 2 , 日本 建築学会計画系論文報告集，第440 号, pp. 89-98, 1992.10

15) 瀬田惠之，松本直司，青野文晃，河野俊樹，武者利光：ゆらぎ理論に基づ く街路樹と建物の変化が街路景観の乱雑・整然性及び魅力度に与える影響 , 中心市街地に㧈ける乱雑・整然性に関する研究 その 3 , 日本建築学会計 画系論文集，第 561 号, pp. 181-188, 2002.11

16) ケビン・リンチ (著)，丹下健三（訳），富田玲子（訳）：都市のイメージ, 岩波書店, 1968

17) 津川康雄 : 地域とランドマーク象徵性・記号性・場所性, 古今書院, 2003

18) 芦原義信 : 続・街並みの美学, 岩波書店, 1983

19) 鮫島敦, 日本電波塔株式会社 (監修) : 東京タワー 50 年, 日経ビジネス人文庫, 2008

20) 大竹由夏、花里俊廣: 漫画「島耕作シリーズ」に描かれる東京タワーの情景, 日本建築学会大会学術講演梗概集 F-2, pp. 369-370, 2012.9

21) 上田拓治 : 44 の例題で学ぶ統計的検定と推定の解き方, オーム社, 2009 


\title{
A STUDY ON VISIBLE, RECOGNIZABLE AND \\ NON-RECOGNIZABLE AREAS AT THE SURROUNDING STREETS \\ OF THE TOKYO TOWER
}

\author{
Yuka OTAKE* and Toshihiro HANAZATO**
}

* Ph. D. Program, Graduate School of Comprehensive Human Sciences, Univ. of Tsukuba, M. Des.
** Prof., Graduate School of Comprehensive Human Sciences, Univ. of Tsukuba, Dr. Eng.

In Japan, there are many places considered landmarks such us Edo-Mi or Fuji-Mi, which their importance and affection as landmarks has been attached to the place for many years. Further, the buildings of the central part of the cities in Japan, are upper-layersized where landmarks are decreasing in number. One example is the case of The Tokyo Tower, which if its possible to recognize it but with little visibility.

This situation might occur because many recognizable areas of the Tokyo Tower such as the top part is used to be hidden by trees or buildings of the surronnding area. Therefore, this study contributes to define the following terms: "the visible area" , "the recognizable area" and "the non-recognizable area". The first term belongs to those areas where the Tokyo Tower can only be recognizable and the second term corresponds to those areas where it can be seen but not recognizable. Cosequently, the purpose of this study is to clarify "the visible area" , "the recognizable area" and "the non-recognizable area" in surrounding streets of the Tokyo Tower.

In the second chapter, the study investigates the figure' s recognition of the Tokyo Tower through pictures taken from different streets locations and interviews. Results evidenced that is hard to recognize the figure of the Tokyo Tower because of the amount of trees and buildings in the area. On the other hand, interviews have revealed that a certain portion of the Tokyo Tower can be seen through a large observation from a hight of $150 \mathrm{~m}$ from the ground, which facilitates the perception to recognize the figure of the Tokyo Tower. Therefore, "the recognizable areas" were defined as the area swhere the Tokyo Tower can be seen trough a large observation and "the non-recognizable areas" as the areas where it cannot be seen during the same long period of time.

In the third chapter, the study investigates the figure of the Tokyo tower around the streets and examines the relationship between the visible areas on streets and the viewing distance within a-1000 meter radius. In some areas within a-500 meter radius, the visibility of the Tokyo Tower is less than within a-1000meter radius. The visibility decrease proportionally according to the viewing distance and it is difficult to recognize the areas where the Tokyo Tower unexpectedly appears.

In the fourth chapter, the study identifies the recognizable areas on the city map and the recognizable streets areas with their corresponding viewing distance. As a result, an inverse proportional relation of the viewing distance and recognizable areas was found in particular streets located in the west, northwest and south areas from the Tokyo Tower

In addition, the recognizable areas are presented in particular and few streets within a-200-meter radius where it is possible the recognition of the Tokyo Tower due to the top part visibility regardless the tower is hidden by trees or buildings.

In the fifth chapter, the non-recognizable areas were defined as the areas where the Tokyo Tower can be visible but not recognized, these areas were increasable identified above the 200 meters radio.

Finally, results have showed that if something is designed the top of the Tokyo Tower, it can be easly recognize. Additionally, the non-recognizable areas of Tokyo Tower evidenced in this paper turns into the recognizable areas and those areas could icrease in number. 